Int. J. Electrochem. Sci., 13 (2018) $8496-8505$

International Journal of

ELECTROCHEMICAL

SCIENCE

www.electrochemsci.org

\title{
In-situ Synthesis of an Auxiliary Electrode of Solid Electrochemical Sulfur Sensor by $\mathrm{CaAl}_{4} \mathrm{O}_{7}$ Coating
}

Tianpeng Wen, Jingkun Yu*, Tao Liu, Endong Jin, Xinghui Hou, Yuting Zhou

School of Metallurgy, Northeastern University, Shenyang 110819, PR China

*E-mail: $\underline{\text { han921224@ sina.com }}$

doi: $10.20964 / 2018.09 .34$

Received: 16 May 2018 / Accepted: 2 July 2018 / Published: 5 August 2018

A novel auxiliary electrode $\mathrm{CaAl}_{4} \mathrm{O}_{7}+\mathrm{Al}_{2} \mathrm{O}_{3}+\mathrm{CaS}$ used for solid electrochemical sulfur sensor, was synthesized by the in-situ reaction of $\mathrm{CaAl}_{4} \mathrm{O}_{7}$ coating on the surface of the $\mathrm{ZrO}_{2}(\mathrm{MgO})$ electrolyte tube by: $\mathrm{CaAl}_{4} \mathrm{O}_{7}+[\mathrm{S}]=\mathrm{CaS}+2 \mathrm{Al}_{2} \mathrm{O}_{3}+[\mathrm{O}]$. The $\mathrm{CaAl}_{4} \mathrm{O}_{7}$ coating was synthesized using aluminum nitrate solution and calcium hydroxide solution as raw materials and then was fabricated on the surface of the $\mathrm{ZrO}_{2}(\mathrm{MgO})$ electrolyte tube using solid sintering technology at $1500{ }^{\circ} \mathrm{C}$. The microstructure of the coating was dense and well combined with the $\mathrm{ZrO}_{2}(\mathrm{MgO})$ electrolyte. The solid electrochemical sulfur sensor $\mathrm{Fe}\left|[\mathrm{S}]_{\mathrm{Fe}}\right| \mathrm{CaAl}_{4} \mathrm{O}_{7}\left|\mathrm{ZrO}_{2}(\mathrm{MgO})\right| \mathrm{Cr}+\mathrm{Cr}_{2} \mathrm{O}_{3} \mid \mathrm{Mo}$ was assembled and tested in the carbonsaturated molten iron at $1500{ }^{\circ} \mathrm{C}$. The results showed that the sensor had a good stability and accuracy, and the $\mathrm{CaAl}_{4} \mathrm{O}_{7}$ coating was converted to $\mathrm{CaAl}_{4} \mathrm{O}_{7}+\mathrm{Al}_{2} \mathrm{O}_{3}+\mathrm{CaS}$ when the sulfur sensor was inserted into the molten iron. The phase composition and microstructure of the synthetized auxiliary electrode were investigated after the sulfur sensor was tested, indicating that the auxiliary electrode coating with a thickness of 40-50 $\mu \mathrm{m}$ was synthetized. The empirical formula of the sulfur sensor was obtained as follows:

$E(\mathrm{mV})=45.891 \mathrm{n}[\mathrm{wt} \% \mathrm{~S}]+24.39$

Keywords: Coating; Auxiliary electrode; Sulfur sensor; Solid electrolyte; In-situ synthesis

\section{$\underline{\text { FULL TEXT }}$}

(C) 2018 The Authors. Published by ESG (www.electrochemsci.org). This article is an open access article distributed under the terms and conditions of the Creative Commons Attribution license (http://creativecommons.org/licenses/by/4.0/). 